\title{
Citizenship Ability, Homestead Utility, and Rural Homestead Transfer of "Amphibious" Farmers
}

\author{
Zhongyou Yuan ${ }^{1,2}$, Chenchen Fu ${ }^{1}$, Shujie Kong ${ }^{3}$, Jifeng Du ${ }^{1,2}$ and Wei Li ${ }^{1,2,4, *}$ \\ 1 School of Public Administration, South China Agricultural University, Guangzhou 510642, China; \\ yuanzhongyou@scau.edu.cn (Z.Y.); 15871741996@163.com (C.F.); dujifeng@scau.edu.cn (J.D.) \\ 2 Key Laboratory of Natural Resources Monitoring in Tropical and Subtropical Area of South China, \\ Guangzhou 510642, China \\ 3 School of Public Affairs, Zhejiang University, Hangzhou 310058, China; 12022086@zju.edu.cn \\ 4 Southern Marine Science and Engineering Guangdong Laboratory (Zhuhai), Sun Yat-sen University, \\ Zhuhai 519000, China \\ * Correspondence: liwei289@sysu.edu.cn
}

Citation: Yuan, Z.; Fu, C.; Kong, S.; Du, J.; Li, W. Citizenship Ability,

Homestead Utility, and Rural

Homestead Transfer of "Amphibious"

Farmers. Sustainability 2022, 14, 2067. https://doi.org/10.3390/su14042067

Academic Editor: Giuseppe Todde

Received: 6 December 2021

Accepted: 7 February 2022

Published: 11 February 2022

Publisher's Note: MDPI stays neutral with regard to jurisdictional claims in published maps and institutional affiliations.

Copyright: (c) 2022 by the authors Licensee MDPI, Basel, Switzerland. This article is an open access article distributed under the terms and conditions of the Creative Commons Attribution (CC BY) license (https:// creativecommons.org/licenses/by/ $4.0 /)$.

\begin{abstract}
Rural homestead transfer is of considerable significance for the revitalization of rural land assets and sustainable use of land resources. "Amphibious" farmers are the most likely to transfer their homestead. As such, it is important to study their transfer behavior and influencing factors to promote homestead transfer. The study involved distributing questionnaires to 768 "amphibious" farmers in Guangdong Province, China, and 747 samples were valid. The impact of the farmers' citizenship ability and homestead utility preference on their homestead transfer behavior was analyzed using a binary logistic model. The study found that: (1) the citizenship ability of "amphibious" farmers had a significant positive impact on their willingness; the stronger the citizenship ability was, the stronger the willingness to transfer homesteads was. (2) Property and the guarantee utility of the homestead have an opposite impact on the willingness of "amphibious" farmers to transfer their homestead; if the property utility of the homestead is strong, its transfer intention is strong, but if the guarantee effect is strong, its transfer intention is weak. If the amphibious farmers are older, more educated, and have longer working years in cities, their willingness to transfer homestead will be lower. (3) The "amphibious" farmers working in cities and towns were found to have a stronger willingness to transfer homestead than those working in rural areas. Hence, the government should formulate differentiated policies for homestead transfer according to the ability endowment of farmers, improve various urban services and security infrastructure based on the urban housing of "amphibious" farmers, weaken the security utility of their rural homestead to flexibly realize their homestead property value, help them become citizens, and promote homestead transfer.
\end{abstract}

Keywords: "amphibious" farmers; willingness of homestead transfer; citizenship ability; homestead utility; binary logistic regression

\section{Introduction}

Since the open reform, China's urbanization rate has increased from $17.92 \%$ in 1978 to $63.89 \%$ in 2020. Nearly 670 million farmers have moved to cities. This large-scale migration has led to significant changes in the relationship of urban and rural areas. Theoretically this will lead to the reduction of rural residential area and an increase in urban housing. However, the total size of homesteads has not decreased but increased with continuous population migration. Due to China's long-term implementation of the dual division of urban and rural areas and the urbanization of "diminishing land without transforming people" (hua di bu hua ren), a special type of farmer named "amphibious" farmers have appeared. On the one hand, amphibious farmers' registered residences are in rural areas, and they can own their rural homestead in the village. On the other hand, they have the ability to work and settle down in cities and purchase real estate. In earlier times, scholars 
defined amphibious farmers as "rural semi-urbanized floating people, working in the city and settled down in the countryside". They are engaged in agricultural activities in the farming seasons and engaged in non-agricultural activities such as industry, construction, transportation and commercial services in the slack seasons [1]. Later scholars found these farmers became social members with dual class attributes, who kept their identity as farmers and acted more like urban citizens [2]. Some defined amphibious farmers as "one identity and two occupations combing with agricultural and non-agricultural industries, working in the city with old houses in rural areas and a new home in the city" [3,4]. They are engaged less in agricultural activities and more in non-agricultural activities. Due to the Chinese household registration system, these farmers cannot easily change their registered residence in rural areas. This unique type of "amphibious" farmer has a dual land occupation in urban and rural areas, which has caused the imbalance between the supply and demand of urban construction land and housing, homesteads being left idle and inefficiently used, and illegal construction [5].

Existing research has realized the importance of homestead transfer in terms of farmers' attempts besides policy and government factors [6,7]. Zhang suggested that farmers should be guided and encouraged to withdraw their homestead from the perspective of farmers' benefits [8]. Zhao et al. investigated that the proportion of non-agricultural income in total income, the understanding of homestead policies and the education level have a positive impact on the farmers' attempts to transfer their homestead [9]. Xu and Liu found that the distance of homesteads from cities and towns has a negative impact on homestead transfer [10]. However, most of them consider farmers as a homogeneous population to investigate the influencing factors of farmers' attempts and pay less attention to classifying the farmers. Some research showed that farmers with non-agricultural employment have a different understanding of rural homestead transfer. Most of them work out of villages and do not consider their rural homestead as their only settlement, which provides more of a possibility to achieve the rural house transfer [11,12].

Therefore, it is meaningful to classify farmers to investigate the influencing factors of their attempts at homestead transfer. "Amphibious" farmers have a high chance of transferring their rural homestead. As the data is difficult to obtain, few studies have discussed it. In our research, we tried to focus on this special group of farmers and raised the following research question. What are the influencing factors of whether amphibious farmers transfer their rural homestead? This research tried to enrich the investigation of the differentiation of farmers' attempts at homestead transfer.

\section{Literature Review}

\subsection{Influencing Factors of Amphibious Farmers' Attempts at Transferring Their Rural Homestead}

Previous studies have discussed the influencing factors of farmers' attempts at transferring rural homestead mainly from two perspectives. The first perspective is the characteristics of farmers, such as the gender and age, status of non-agricultural employment, non-agricultural income and place of employment [13,14]. The second perspective is the function of the homestead. Lv and Zhao suggested that the function of the security and welfare of a homestead influence the issue of land compensation for farmers [15]. In the research, we followed these two perspectives and focused on amphibious farmers.

Firstly, the most significant characteristic of amphibious farmers is their citizenship ability, which is different from previous studies on homogeneous groups of farmers [4]. After 40 years of reform and opening the country, rural man-land relationships and urbanrural relationships in China have displayed new characteristics [16-19]. A survey shows that more and more rural migrant workers want to stay in cities, especially the new generation of migrant workers, and the proportion of them willing to settle in cities and towns is as high as $91.2 \%$ [20]. However, the citizenship intention is only the driving force behind citizenization. Whether it can be truly realized depends on citizenship ability, that is, the ability to settle and survive in cities and towns [21]. Research shows that only those farmers who were educated [13], had a significant proportion of non-agricultural 
income [22], and had a strong family livelihood [23], especially those who purchased houses in cities or towns, tended to give up rural homesteads and live in cities. In other words, only when urban life is guaranteed and the security needs of economic, social, and political aspects are met to a certain extent, will migrant workers consider giving up their land to completely become citizens [24], and realize the transformation from "farmers" to "migrant workers" and finally to "citizens" through citizenization. This shows that when farmers have a strong ability to settle and survive in cities, their demand for the guarantee function of homesteads will be weakened. Based on the above research, we supposed that there was a positive correlation between citizenship ability and attempts at homestead transfer by amphibious farmers.

Secondly, the function of homesteads is complex for amphibious farmers. The homestead is not only the basic material guarantee for farmers to live and work, and the social guarantee to prevent farmers from being displaced, but also the most important property basis for farmers to obtain more property income [25]. When the social guarantee system is weak, the rural homestead becomes the most important social guarantee for farmers [26]. However, with the non-agriculturalization of farmers' economic activities and the continuous improvement of their income level, as well as the increase in the proportion of farmers who buy houses in cities or towns, the importance of the residential function and living place of the homestead is decreasing, and the utility of farmers' free acquisition and occupation of the homestead is decreasing [27]. Furthermore, the focus of the homestead function has shifted, the guarantee function has been gradually weakened, and the property function has been gradually enhanced $[28,29]$. In the context of the change of homestead function, farmers will have different preferences for homestead function according to their own livelihood mode [30]. Those urban farmers with stable incomes and old-age security will hope to obtain income from land transfer and transfer their rural land [31]. Moreover, with the gradual weakening of the security attribute of the homestead and the continuous strengthening of the property attribute, the willingness of and appeal to farmers to transfer are becoming stronger [32]. Those farmers with urban settlement and living ability will abandon their rural land rights [33], while those farmers with a high dependence on their rural homesteads will be unwilling to quit the homestead. Based on the above analysis, we suppose that the property function of homesteads is positively correlated with homestead transfer and the guarantee function of homesteads is negatively related to the transfer of homesteads.

\subsection{Theoretic Framework}

We tried to find out the influencing factors of amphibious farmers' attempts at transferring their rural homestead from the above two perspectives and built up the theoretical framework shown in Figure 1.

One factor is citizenship ability, which consists of housing affordability, economic capability, and urban integration capability. The process of the citizenization of the rural population is not only reflected in career transformation [34], but also in citizen identity and urban integration [35]. Stable work and income in cities are the economic basis for amphibious farmers to integrate into the city [36], which can also promote their sense of identity as "urban citizens" [37]. Therefore, we consider higher economic income to play a positive role in promoting the urban social integration of amphibious farmers [38,39]. Moreover, housing is an intermediate mechanism for social division and integration [40]. It is not only a material space for social people to shelter, but also determines the living environment and social communication space of urban residents, providing opportunities for social people to obtain various urban resources, accumulate human and social capital, and integrate into the urban mainstream society [41,42]. Particularly for rural migrants, including amphibious farmers, owning urban housing will increase their willingness to stay in the city and promote their citizenization process $[43,44]$.

The other influencing factor is homestead utility, including guarantee and property functions. The homestead is the place and guarantee for farmers to live and work, and it 
is the concrete carrier of farmers' concept of "home" [45]. Therefore, attempts at transferring rural homestead are very much affected by how owners think of their homestead's guarantee function. Moreover, the homestead is also the property of farmers. The wealth accumulation of a farmer's family from generation to generation is mainly reflected in the remaining "ancestral house" [46]. As the financial source of farmers, homesteads can not only obtain property income through leasing and equity investment, but also increase in value over time, bringing property income to farmers. If the homestead is expropriated, it can also obtain compensation income [47].

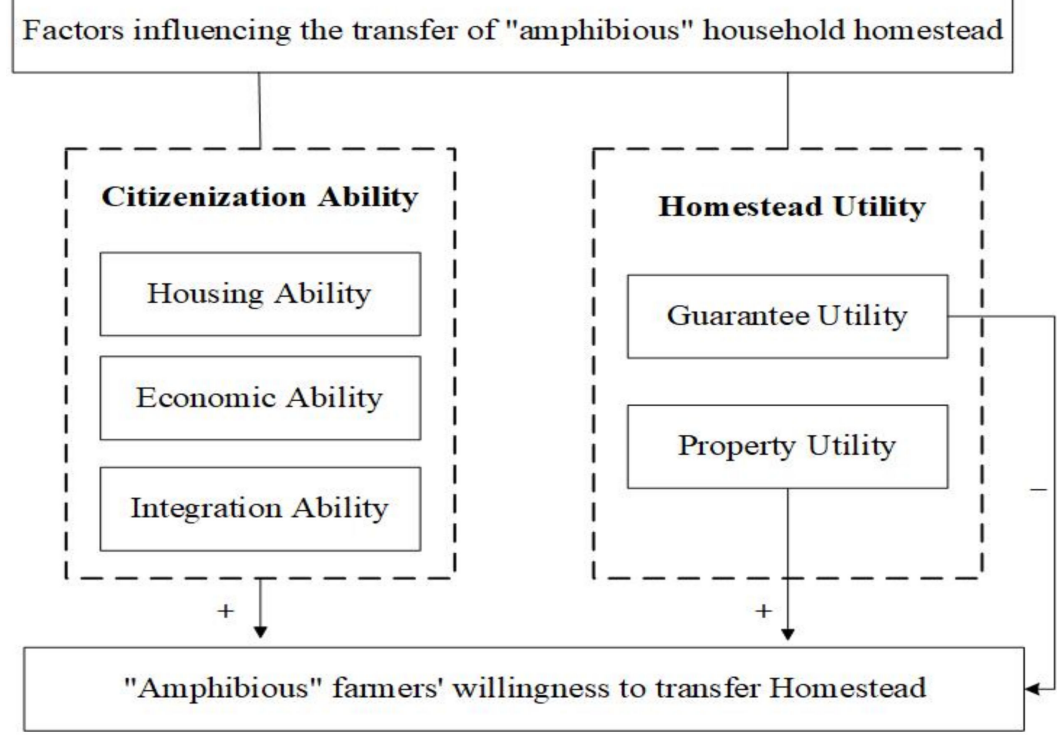

Figure 1. The theoretical analysis framework of the impact of citizenship and homestead utility on the willingness of "amphibious" farmers to transfer homestead. Note: "+" indicates improvement or enhancement, "-" indicates weakening or reduction.

However, with the further acceleration of urbanization and the citizenization of the agricultural transfer population, the homestead increasingly presents cashable potential functions, intergenerational inheritance functions, and land cultural and emotional functions [48]. Its core functions are still guarantee and property functions. Whether farmers transfer their homestead depends on the comparison of the potential benefits generated by guarantee functions and asset functions [49]. Especially since the No. 1 central document issued in 2018, the new policy of "three rights division" has been put forward. The balance between a homestead's function of guarantee and function of property is the key to whether the homestead is transferred. Concerning these two factors, we put forward three hypotheses.

Hypothesis 1 (H1). The stronger the citizenship ability of amphibious farmers, the stronger their willingness to transfer homestead.

Hypothesis 2 (H2). The higher the property utility of amphibious farmers' homestead, the stronger their willingness to transfer homestead.

Hypothesis 3 (H3). The higher the guarantee utility of amphibious farmer households' homesteads, the lower their willingness to transfer their homestead. 


\section{Material and Methods}

\subsection{Research Design}

The research design includes four stages (Figure 2). The first stage is to suggest a hypothesis based on the literature review and research question. We planned to search the literature using key words of "amphibious" farmers and influencing factors to find out the research gap and theory foundation for the hypothesis.

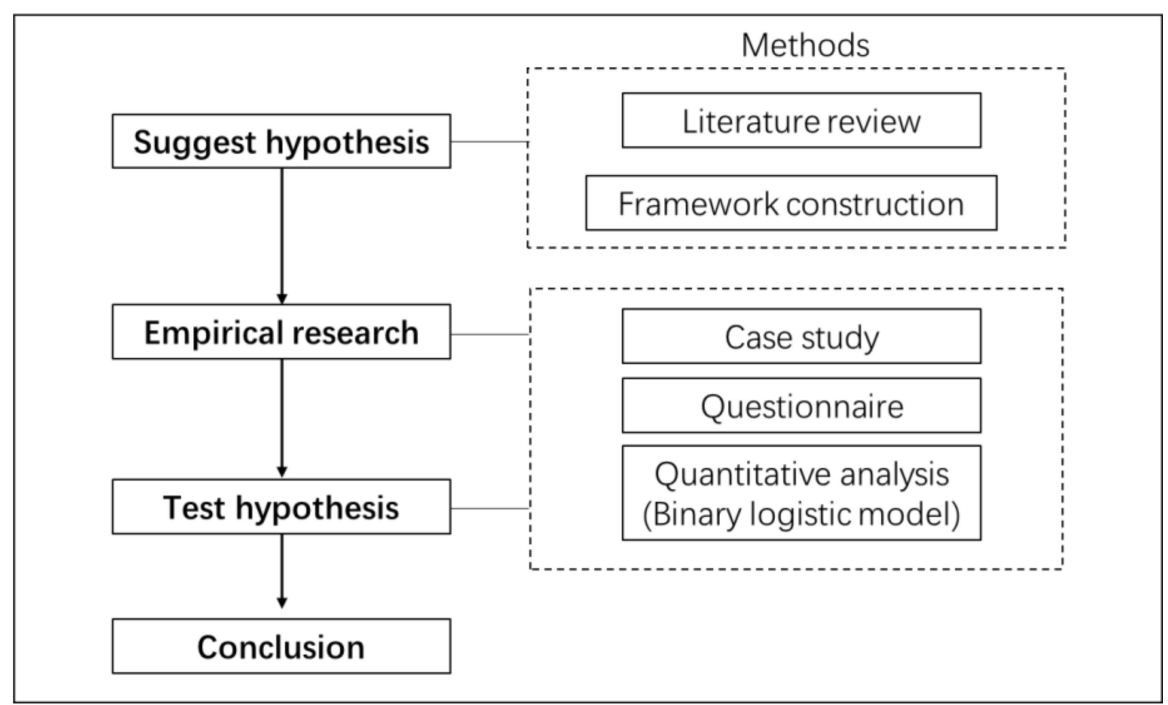

Figure 2. Research design and methods.

The second stage is empirical research. We planned to conduct a questionnaire (can be found in Appendices A and B) targeted at amphibious farmers' attempts at rural homestead transfer in a case area to obtain data. Amphibious farmers are a special group of migrant workers, and their distribution is random. It is difficult to identify them only when you know they have houses both in a city and in a village. They have their own social network which could be a special clue. Furthermore, it would be uneconomical and inefficient to adopt the usual sampling method as the group numbers and the proportion are not clear. Therefore, we planned to adopt snowball sampling to greatly increase the possibility of contacting this special group in the total population. The snowball sampling method starts with the survey objects familiar to the investigators, and then by obtaining more survey objects through them, like a snowball, gradually expand the scope of the sample until a reasonable sample size is obtained [50]. To prevent the inherent methodological limitation of snowball sampling to avoid biased results, we tried to do the sampling in different regions in the case area, which has a certain sample size and heterogeneity. Moreover, during the investigation, the triangular mutual verification method was adopted to ensure the quality of the data [51].

The third stage is to test the hypothesis with a quantitative analysis with data. The fourth stage comes to a conclusion and finds out the possible influencing factor of amphibious farmers' attempts at rural homestead transfer.

\subsection{Case Study}

We chose Guangdong province as a case study for two reasons. Firstly, amphibious farmers are more likely to appear in Guangdong province as its rural economy has developed fast and well. Guangdong province is at the forefront of opening up reform and is well developed in economic, social, and cultural aspects. Its industrialization and urbanization has developed well and lots of migrant workers from rural areas work in cities. According to the results of the third national agricultural census in Guangdong Province, there are $1,158,400$ farmers purchasing real estate in cities or towns [52]. In 2021, the per capita disposable income of rural residents in Guangdong was CNY 22,306, an increase of 10.7\%, 
much higher than that of the nation (CNY 18,931) [53]. Secondly, Guangdong province is also a pioneer area of reform of rural homestead transfer. Numerous regulations and policy practices have been implemented in Guangdong where farmers are open-minded and willing to answer questions on their private homestead and core profits.

\subsection{Process of Survey in Questionnaire}

We conducted the survey in Guangdong Province in 2019. The survey includes three steps. Step 1: from January to March 2019, a questionnaire was designed according to the research purpose of the subject. Step 2: April 2019, the pre-survey was carried out, and the final questionnaire was completed. Step 3: from May to August 2019, 32 experienced and trained investigators who are Guangdong registered residents and students returned to their hometowns to investigate "amphibious" farmers face-to-face. The respondents were mainly householders or their spouses, and each questionnaire was about 25 min long.

The questionnaire questions include farmers' personal and family characteristics, status of rural homestead, level of citizenship ability, and the willingness of the homestead transfer. The questionnaire adopted a 5-point Likert scale method, and the meaning of assignment ranges from "very poor" to "very good" (Appendices A and B). A total of 768 questionnaires were distributed. Due to it being a face-to-face survey, all the questionnaires were recovered, and the recovery rate was $100 \%$.

\subsection{Model Setting}

The main purpose of this paper is to investigate "amphibious" farmers' homestead transfer intention and its influencing factors, taking the "amphibious" farmers' homestead transfer intention as the dependent variable $Y$, and the factors affecting the willingness of "amphibious" farmers to transfer their homestead as the independent variable $X$. The dependent variable "willingness of homestead transfer" has only two possibilities, namely "willing" and "unwilling" transfer, which is a binary variable. Therefore, the binary logistic regression model was used for analysis. By analyzing the relationship between $Y$ and $X$, the influencing factors and contribution value of the willingness of "amphibious" farmers' homestead transfer can be clearly reflected. The basic form of the model is:

$$
\ln \left(\frac{p(y=1)}{1-p(y=1)}\right)=\alpha+\sum_{i=1}^{k}\left(\beta_{i} x_{i}\right)
$$

Then the probability of homestead transfer by "amphibious" farmers is:

$$
p(y=1 \mid x)=\frac{e^{\alpha+\sum_{i=1}^{k} \beta_{i} x_{i}}}{1+e^{\alpha+\sum_{i=1}^{k} \beta_{i} x_{i}}}
$$

In Formulas (1) and (2), $X_{i}$ represents the $i$ explanatory variable affecting the willingness for homestead transfer by "amphibious" farmers and $k$ is the number of explanatory variables, $\alpha$ is the intercept term, and $\beta_{i}$ is the coefficient of the explanatory variable $X_{i}$, reflecting the direction and degree of the impact of the variable on the willingness for homestead transfer by "amphibious" farmers, which is usually obtained by the maximum likelihood estimation method. The ratio $\frac{p(y=1)}{1-p(y=1)}$ is the event occurrence ratio, which is the probability of "amphibious" farmers being willing to transfer homestead or unwilling to transfer homestead, and $e^{\beta_{i}}$ reflects the multiple of the change of the event occurrence ratio caused by each unit of the explanatory variable $X_{i}$.

In order to make the results of empirical analysis more robust and reliable in the binary logistic analysis, the core explanatory variables were included in three steps to construct the analysis model. After the control variables were included, only the core explanatory variables such as guarantee utility were included in Model (1). Model (2) included two core explanatory variables: guarantee utility and property utility after the control variables were included. Model (3) included three core explanatory variables: guarantee utility, property utility, and citizenship ability after the control variables were included. 


\section{Results}

\subsection{Descriptive Statistics by “Amphibious" Farmers' Willingness of Homestead Transfer}

The valid survey data numbered 747, and the characteristics were as follows: (1) Gender distribution: there were 422 men, accounting for $56.49 \%$ of the total; there were 325 women, accounting for $43.51 \%$ of the total. (2) Age distribution: there were 115 people aged 20-30, accounting for $15.39 \%$ of the total; 204 people aged 31 to 40 , accounting for $27.31 \%$ of the total; 291 people aged 41 to 50, accounting for 38.96\% of the total; 107 people aged 51 to 60, accounting for $14.32 \%$ of the total; and 30 people over the age of 61 , accounting for $4.02 \%$ of the total. (3) Education distribution: there were 81 people with primary school education and below, accounting for $10.84 \%$ of the total; 216 people with junior middle school education, accounting for $28.92 \%$ of the total; 163 people with high school education, accounting for $21.82 \%$ of the total; 134 people with specialized education, accounting for $17.94 \%$ of the total; and 153 people with bachelor's degrees or above, accounting for $20.48 \%$ of the total. (4) Annual household income distribution: 20 households earned below CNY 20,000, accounting for 2.68\% of the total; 99 households with CNY 20,000 to 60,000, accounting for $13.25 \%$ of the total; 184 households with CNY 70,000 to 110,000 , accounting for $24.63 \%$ of the total; 229 households with CNY 120,000 to 160,000, accounting for $30.66 \%$ of the total; and 215 households above 160,000 yuan, accounting for 28.78\% of the total. (5) Regional distribution: there were 215 households in northern Guangdong, accounting for $28.78 \%$ of the total; 243 households in the east and west wings, accounting for $32.53 \%$ of the total; and 289 households in the Pearl River Delta, accounting for $38.69 \%$ of the total.

Table 1 presents the reliability test results of measurement indicators. The calculation results show that the Cronbach's alpha value of homestead utility is greater than 0.6 , and the Cronbach's alpha value of citizenship ability is greater than 0.7 , indicating that the variable has good reliability. In addition, the principal component analysis was carried out on 13 observed variables in guarantee utility, property utility, economic ability, integration ability, and housing ability; the KMO value of the model is 0.700 ; and the Bartlett's spherical test values were significant at the statistical standard of $1 \%$.

80 per cent of "amphibious" farmers were satisfied with the living environment and conditions of their rural houses. A total of 74.83\% of "amphibious" farmers think homesteads can give them a sense of family belonging. Secondly, in terms of property utility in homestead utility, $62.11 \%$ of "amphibious" farmers agree that compensation for homestead demolition and requisition will bring them greater economic benefits, and $10.32 \%$ of "amphibious" farmers thought that homestead demolition and requisition will not bring them greater economic benefits. More than half $(54.48 \%)$ of the "amphibious" farmers believe that their homestead can obtain greater benefits in the process of transfer, and about $17.01 \%$ of the "amphibious" farmers believe that homestead transfer will not bring them greater benefits. Thirdly, in terms of economic ability in citizenship ability, $59.43 \%$ of the "amphibious" farmers have an annual income of more than CNY 110,000, indicating that the annual income of the "amphibious" farmers is in a good condition. However, only $27.00 \%$ of the "amphibious" farmers accepted the price levels in the city where they live. In total, $85.00 \%$ of "amphibious" farmers believe that their non-agricultural livelihood skills are sufficient or able to cope with urban life. Fourthly, in terms of integration ability in citizenship ability, nearly half of "amphibious" farmers (nearly 46.31\%) have some difficulties in integrating into the new urban life and still believe that $(68.13 \%)$ they have the strong ability to get involved in urban life. Fifthly, in terms of housing capacity in citizenship ability, up to $95.00 \%$ of "amphibious" farmers are satisfied or relatively satisfied with the living environment, public supporting facilities, and community facilities of their urban houses, and only 5.00\% of "amphibious" farmers are dissatisfied with the living environment of their urban houses. 
Table 1. Reliability test results of measurement indicators.

\begin{tabular}{|c|c|c|c|c|c|c|}
\hline Criterion Layer & Latent Variable & Variable & Mean & SD & $\begin{array}{l}\text { Item's Deleted } \\
\text { Alpha Value }\end{array}$ & $\begin{array}{l}\text { Cronbach's } \\
\text { Alpha Value }\end{array}$ \\
\hline \multirow{5}{*}{$\begin{array}{l}\text { Homestead } \\
\text { utility }\end{array}$} & \multirow{3}{*}{$\begin{array}{l}\text { Guarantee } \\
\text { utility }\end{array}$} & $\begin{array}{l}\text { Satisfaction with rural house } \\
\text { living environment }\end{array}$ & 3.31 & 0.79 & 0.609 & \multirow{5}{*}{0.638} \\
\hline & & $\begin{array}{l}\text { Satisfaction with rural house } \\
\text { living conditions }\end{array}$ & 3.22 & 0.89 & 0.617 & \\
\hline & & $\begin{array}{l}\text { The homestead with a sense of } \\
\text { family belonging }\end{array}$ & 3.99 & 0.88 & 0.602 & \\
\hline & \multirow{2}{*}{ Property utility } & $\begin{array}{l}\text { Large compensation value for } \\
\text { demolition and requisition }\end{array}$ & 3.78 & 0.99 & 0.532 & \\
\hline & & $\begin{array}{l}\text { Large income from } \\
\text { homestead transfer }\end{array}$ & 3.61 & 1.12 & 0.549 & \\
\hline \multirow{8}{*}{$\begin{array}{l}\text { Citizenship } \\
\text { ability }\end{array}$} & \multirow{2}{*}{$\begin{array}{l}\text { Economic } \\
\text { ability }\end{array}$} & $\begin{array}{l}\text { Annual household income } \\
\text { (CNY 10,000) }\end{array}$ & 3.70 & 1.10 & 0.685 & \multirow{8}{*}{0.707} \\
\hline & & Acceptance of urban prices & 2.85 & 0.91 & 0.702 & \\
\hline & \multirow{3}{*}{$\begin{array}{l}\text { Integration } \\
\text { ability }\end{array}$} & Non-agricultural livelihood skills & 3.18 & 0.75 & 0.684 & \\
\hline & & $\begin{array}{l}\text { Compared with the self-feeling of } \\
\text { urban residents }\end{array}$ & 2.92 & 0.98 & 0.689 & \\
\hline & & Acceptance of new urban life & 3.51 & 0.80 & 0.696 & \\
\hline & \multirow{3}{*}{ Housing ability } & Satisfaction with urban housing & 3.59 & 0.77 & 0.660 & \\
\hline & & $\begin{array}{l}\text { Satisfaction with public } \\
\text { supporting facilities of } \\
\text { urban housing }\end{array}$ & 3.49 & 0.82 & 0.649 & \\
\hline & & $\begin{array}{l}\text { Satisfaction with urban housing } \\
\text { community facilities }\end{array}$ & 3.50 & 0.83 & 0.655 & \\
\hline
\end{tabular}

\subsection{Binary Logistic Results on "Amphibious" Farmers' Willingness of Homestead Transfer}

The test results show that the maximum variance expansion factor (VIF) of the selected explanatory variables is 2.255 and the minimum is 1.134 , which can determine that there is no collinearity problem between the explanatory variables of the model.

Table 2 presents estimation results of the binary logistic model. According to the fitting information of the regression model, the omnibus test results of the model coefficients show that the chi square values of Model (1), (2), and (3) are 32.964, 56.496, and 123.683, respectively, and the $\mathrm{P}$ values are less than 0.000 . The Hosmer-Lemeshow goodness of fit test results show that the chi square values of Model (1), (2), and (3) are 17.186, 8.947, and 7.171, respectively, and the $P$ values are $0.124,0.347$, and 0.518 , respectively, which are greater than 0.05 , indicating that the model has a goodness of fit and is suitable for the binary logistic regression model. The direction and size of independent variables can be analyzed and judged by regression results.

Among the 747 "amphibious" farmers in Guangdong Province, 225 of them actually transferred their homesteads, accounting for $30.12 \%$; this rate is higher than the homestead transfer rate of ordinary farmers in Wuhan (18.97\%), surveyed by Guan and Huang (2013), and the homestead transfer rate of ordinary farmers in Wenzhou (13.15\%), surveyed by Qian et al. (2015), indicating that "amphibious" farmers' willingness to transfer their homestead is higher than that of ordinary farmers.

The estimation results of Model (3) including all variables show that under the control of individual characteristic variables of farmers, six of the eight variables that measure the citizenship ability of "amphibious" farmers have a positive impact on their willingness to transfer their homestead; among them, non-agricultural livelihood skills $(\beta=0.782$, $\mathrm{OR}=2.186, p<0.01)$, satisfaction with urban housing $(\beta=0.312, \mathrm{OR}=1.367, p<0.05)$, satis- 
faction with public supporting facilities of urban housing $(\beta=0.567, \mathrm{OR}=0.567, p<0.01)$, and the satisfaction with urban housing community facilities $(\beta=0.570, \mathrm{OR}=1.768$, $p<0.01$ ) had a significant positive impact on their willingness to transfer their homestead. For each unit of "amphibious" farmers' non-agricultural livelihood skills, satisfaction with urban housing, satisfaction with public supporting facilities of urban housing, and satisfaction with urban housing community facilities, their willingness to transfer homestead increased by $2.186,1.367,0.567$, and 1.768 times, respectively. It shows that the stronger the citizenship ability of "amphibious" farmers, the stronger their willingness to transfer homestead. Hypothesis 1 has been verified.

Table 2. Estimation results of binary logistic model.

\begin{tabular}{|c|c|c|c|c|c|c|c|c|}
\hline & \multirow{2}{*}{\multicolumn{2}{|c|}{ Variable Category }} & \multicolumn{2}{|c|}{ Model (1) } & \multicolumn{2}{|c|}{ Model (2) } & \multicolumn{2}{|c|}{ Model (3) } \\
\hline & & & $\beta$ & $\operatorname{Exp}(\beta)$ & $\beta$ & $\operatorname{Exp}(\beta)$ & $\beta$ & $\operatorname{Exp}(\beta)$ \\
\hline \multirow{5}{*}{$\begin{array}{l}\text { Homestead } \\
\text { utility }\end{array}$} & \multirow{3}{*}{$\begin{array}{l}\text { Guarantee } \\
\text { utility }\end{array}$} & $\begin{array}{l}\text { Satisfaction with rural house } \\
\text { living environment }\end{array}$ & $-0.330 * * *$ & 1.391 & $-0.311^{* *}$ & 1.365 & $-0.237^{*}$ & 1.267 \\
\hline & & $\begin{array}{l}\text { Satisfaction with rural house } \\
\text { living conditions }\end{array}$ & -0.158 & 0.854 & -0.171 & 0.843 & $-0.215^{*}$ & 0.806 \\
\hline & & $\begin{array}{l}\text { The homestead with a sense of } \\
\text { family belonging }\end{array}$ & -0.095 & 0.909 & $-0.235^{* *}$ & 0.791 & $-0.198 *$ & 0.821 \\
\hline & \multirow{2}{*}{$\begin{array}{l}\text { Property } \\
\text { utility }\end{array}$} & $\begin{array}{l}\text { Large compensation value for } \\
\text { demolition and requisition }\end{array}$ & & & -0.108 & 1.114 & 0.073 & 1.075 \\
\hline & & $\begin{array}{l}\text { Large income from } \\
\text { homestead transfer }\end{array}$ & & & $0.323 * * *$ & 1.381 & $0.375 * * *$ & 1.455 \\
\hline \multirow{8}{*}{$\begin{array}{l}\text { Citizenship } \\
\text { ability }\end{array}$} & \multirow{2}{*}{$\begin{array}{l}\text { Economic } \\
\text { ability }\end{array}$} & $\begin{array}{l}\text { Annual household } \\
\text { income (CNY 10,000) }\end{array}$ & & & & & $-0.319^{* * *}$ & 0.727 \\
\hline & & Acceptance of urban prices & & & & & 0.156 & 1.169 \\
\hline & \multirow{3}{*}{$\begin{array}{l}\text { Integration } \\
\text { ability }\end{array}$} & Non-agricultural livelihood skills & & & & & $0.782^{* * *}$ & 2.186 \\
\hline & & $\begin{array}{l}\text { Compared with the self feeling of } \\
\text { urban residents }\end{array}$ & & & & & 0.025 & 1.025 \\
\hline & & Acceptance of new urban life & & & & & -0.037 & 0.963 \\
\hline & \multirow{3}{*}{$\begin{array}{l}\text { Housing } \\
\text { ability }\end{array}$} & Satisfaction with urban housing & & & & & $0.312 * *$ & 1.367 \\
\hline & & $\begin{array}{l}\text { Satisfaction with public supporting } \\
\text { facilities of urban housing }\end{array}$ & & & & & $0.567^{* * *}$ & 0.567 \\
\hline & & $\begin{array}{l}\text { Satisfaction with urban housing } \\
\text { community facilities }\end{array}$ & & & & & $0.570 * * *$ & 1.768 \\
\hline \multirow{6}{*}{$\begin{array}{l}\text { Control } \\
\text { Variable }\end{array}$} & \multicolumn{2}{|c|}{ Gender (male as control group) } & -0.214 & 0.808 & -0.229 & 0.795 & -0.269 & 0.764 \\
\hline & \multirow{2}{*}{\multicolumn{2}{|c|}{$\begin{array}{c}\text { Age } \\
\text { Work location (compared with cities and towns) }\end{array}$}} & $-0.198 * *$ & 0.821 & $-0.205^{* *}$ & 0.814 & $-0.204^{* *}$ & 0.815 \\
\hline & & & $-0.287^{* *}$ & 0.751 & -0.229 * & 0.795 & $-0.249 *$ & 0.780 \\
\hline & \multicolumn{2}{|r|}{ Education } & $-0.184^{* *}$ & 0.832 & $-0.214 * * *$ & 0.807 & $-0.235^{* * *}$ & 0.790 \\
\hline & \multicolumn{2}{|r|}{ Years of working in cities } & -0.114 * & 0.892 & $-0.123 *$ & 0.884 & $-0.136^{*}$ & 0.873 \\
\hline & \multicolumn{2}{|c|}{ Constant } & 1.192 & 3.293 & 0.277 & 1.319 & -2.315 & 0.099 \\
\hline
\end{tabular}

Note: $(1)^{*}, * *, * *$ are significant at the level of $10 \%, 5 \%$, and $1 \%$, respectively; (2) $\beta$ is the regression coefficient, "-" is the negative influence; (3) $\operatorname{EXP}(\beta)$ is the OR value, also known as odds ratio or occurrence ratio.

At the same time, Model (3) estimation results show that the two core explanatory variables to measure the property utility of "amphibious" farmers' homesteads have a positive effect on the willingness of "amphibious" farmers to transfer their homestead, among which the income of homestead transfer $(\beta=0.375, \mathrm{OR}=1.455, p<0.01)$ has a significant positive impact on their willingness to transfer their homestead. For each unit, the willingness of "amphibious" farmers to transfer increases by 1.455 times. This shows that the stronger the property effect of a homestead, the more willing "amphibious" farmers are to transfer their homestead, and Hypothesis 2 is verified. 
Model (3) estimation results also show that the satisfaction with rural house living environment $(\beta=-0.237, \mathrm{OR}=1.267, p<0.1)$, satisfaction with rural house living conditions $(\beta=-0.215$, OR $=0.806, p<0.1)$, and a sense of family belonging $(\beta=-0.198$, $\mathrm{OR}=0.821, p<0.1$ - the three core explanatory variables that measure the guarantee utility of a homestead-have a significant negative impact on the willingness of "amphibious" farmers to transfer their homestead. For each unit of "amphibious" farmers' satisfaction with the rural house living environment, the rural house living conditions, and the homestead with a sense of family belonging, their willingness to transfer homestead decreased by $1.267,0.806$, and 0.821 times, respectively. This shows that the stronger the guarantee effect of a homestead, the more reluctant "amphibious" farmers are to transfer their homestead, and Hypothesis 3 has been verified.

From the individual characteristics of "amphibious" farmers, the age of "amphibious" farmers $(\beta=-0.204, \mathrm{OR}=0.815, p<0.05)$, education of head of household $(\beta=-0.235$, $\mathrm{OR}=0.790, p<0.01)$, and years of working in cities $(\beta=-0.136, \mathrm{OR}=0.873, p<0.1)$, and so on, have a significant negative impact on their homestead transfer. The older the "amphibious" farmers are, the more educated they are, and the longer they have been working in cities, the more reluctant they are to transfer their homestead; for each unit with an increase in age, education level, and years of working in cities, their willingness to transfer decreases by $0.815,0.790$, and 0.873 times, respectively. A possible explanation is that the overall income of rural homestead transfer is low. For "amphibious" farmers with a high annual family income, the income brought in by homestead transfer accounts for a small proportion of their family income, and they pay more attention to the intergenerational inheritance function of homesteads and the emotional function of land culture [10]. Highly educated "amphibious" farmers have a better understanding of the current rural policies and the scarcity of land, think that the homestead has appreciation potential, are unwilling to transfer their homestead cheaply, and thus have a wait-and-see attitude towards the transfer of their homestead. The older "amphibious" farmers have deeper feelings for and stronger dependence on rural areas and homesteads, so their willingness to transfer is lower than that of young farmers. Working in the countryside $(\beta=-0.249, \mathrm{OR}=0.780$, $p<0.1$ ) has a significant negative impact on the homestead transfer of "amphibious" farmers. The "amphibious" farmers working in cities or towns are more willing to transfer their homestead than the "amphibious" farmers working in rural areas. The possible explanation is that the "amphibious" farmers who work in cities or towns all year round have adapted to urban life and are unwilling to return to the countryside, hoping to transfer their homestead and realize the property value of their homestead, thus helping in becoming an urban resident.

\section{Discussion}

\section{Meanings of Citizenship Ability and Homestead Efficiency Preference of "Amphibious" Farmers}

Most research considers farmers to be a homogeneous population to discuss its influencing factors of attempts at rural homestead transfer [8-10]. In our survey, we argued that with the differentiation of occupation and income, it is necessary to consider "amphibious" farmers as a special group based on its dual homestead occupation in rural and urban areas [54,55]. It was found that the potential rate of homestead transfer in the groups of "amphibious" farmers in Guangdong Province is $30.12 \%$. This is much higher than other surveys of non-amphibious farmers in Wuhan (13.15\%) [56] and Wenzhou cases $(13.15 \%)$ [57,58]. During the process of rural industrialization and urbanization, the ruralurban linkages become more and more diverse and complex. Amphibious farmers are representative actors to make rural-urban linkages as they have properties both in urban and rural areas. Therefore, when we discuss rural homestead transfer, it is important to classify the groups of amphibious farmers and consider their interests not only in rural villages, but also in towns and cities.

The research attempted to find out the influencing factors of amphibious farmers' attempts at rural homestead transfer. According to our results, we found a positive cor- 
relation between citizenship ability and attempts at homestead transfer by amphibious farmers. In addition, the property function of homesteads is positively correlated with homestead transfer, and the guarantee function of homesteads is negatively related to the transfer of homesteads.

Some factors seem similar to non-amphibious farmers, such as the positive effect of farmers' citizenship abilities. Peng and Liu found that farmers who have a stronger ability to settle down in a city have more willingness to transfer their rural homestead [18,22]. In addition, we have proven the hypothesis that amphibious farmers are inclined to weaken the security function of their rural homestead because they have the ability to settle down in cities and no need to maintain their rural homestead.

However, some findings contrast ours. $\mathrm{Xu}$ and Liu found that farmers who are educated are more likely to transfer their rural homestead as they are open-minded and understand the meaning of the policy of rural homestead transfer [10]. In contrast, we found that the more educated amphibious farmers are, the less willing they are to transfer rural homestead. Actually, a rural homestead has multiple functions, such as security, culture, and ecology [59]. Educated amphibious farmers may evaluate rural homesteads not only from the physical side, but also from the cultural and spiritual side [58]. Thus, they evaluate their rural homestead for more potential profits, and are not willing to transfer with less money. In other words, when negotiating with amphibious farmers, it would cost much more compensation money than non-amphibious farmers, which previous studies easily neglected.

\section{Conclusions}

Rural homestead transfer is beneficial for increasing the efficiency of rural land use and rural sustainability. Though the existing research realized the importance of farmers' role in homestead transfer, they paid less attention to classifying groups of farmers. This study tried to discuss farmers' attempts at rural homestead transfer from a typical and specific group of "amphibious" farmers, who own homesteads both in rural and urban areas and have a higher potential to transfer their rural homestead, which highlights the importance of the classification of farmers when analyzing their attempts at rural homestead transfer.

Furthermore, the study revealed that citizenship ability and preference of homestead utility affect their transfer behavior through binary logistic analysis on 747 valid cases in Guangdong province. This study proved the three hypotheses that the stronger the citizenship ability is, the stronger the willingness to transfer homesteads is; if the property utility of a homestead is stronger, its transfer possibility is stronger; and if the guarantee utility of a homestead is stronger, its transfer possibility is stronger. This study also found that the willingness of "amphibious" farmers to transfer their homestead is also affected by individual and family characteristics. The older the "amphibious" farmers are, the more educated they are, and the longer they have been working in cities, the more reluctant they are to transfer their homestead. Amphibious farmers working in cities or towns are more willing to transfer their homestead than those working in rural areas.

We suggest the current policy should be guided to affect citizenship ability and preference of homestead utility to influence the willingness of amphibious farmers' rural homestead transfer. In the future, we will make more comparable studies to distinguish drivers and factors among farmers with different characteristics. 
Author Contributions: Conceptualization, Z.Y. and W.L.; methodology, Z.Y.; validation, Z.Y., C.F. and S.K.; formal analysis, S.K. and J.D.; investigation, Z.Y. and J.D.; resources, Z.Y. and W.L.; writing-original draft preparation, Z.Y. and S.K.; writing—review and editing, Z.Y. and W.L.; project administration, Z.Y. and W.L.; funding acquisition, Z.Y. and W.L. All authors have read and agreed to the published version of the manuscript.

Funding: This research was funded by the Ministry of Education Humanities and Social Sciences Research Planning Fund, grant number 18YJAZH121; the general project of "Third-tenth Five-Year Plan" in 2018 for Guangdong Province Philosophy and Social Sciences, grant number GD18CGL11. The research was also funded by the National Natural Science Foundation of China, 41901192, and supported by the Key Laboratory of Natural Resources Monitoring in Tropical and Subtropical area of South China.

Institutional Review Board Statement: Not applicable.

Informed Consent Statement: Informed consent was obtained from all subjects involved in the study.

Conflicts of Interest: The authors declare no conflict of interest.

\section{Appendix A. Core Independent Variables and Their Assignment in Questionnaire}

\begin{tabular}{|c|c|c|c|}
\hline \multicolumn{3}{|c|}{ Variable Name } & Variable Assignment \\
\hline \multirow{8}{*}{$\begin{array}{l}\text { Citizenship } \\
\text { Ability }\end{array}$} & \multirow[b]{2}{*}{ Economic Ability } & Annual household income (CNY 10,000) & $1=2$ or less, $2=2-6,3=7-11,4=12-16,5=16$ and above \\
\hline & & Acceptance of urban prices & $\begin{array}{c}1=\text { Totally unacceptable, } 2=\text { Less acceptable, } 3=\text { Commonly, } \\
4=\text { Quite acceptable, } 5=\text { Totally acceptable }\end{array}$ \\
\hline & \multirow{3}{*}{ Integrate Ability } & Non-agricultural livelihood skills & $\begin{array}{c}1=\text { Very weak, } 2 \text { = Relatively weak, } 3=\text { Commonly, } \\
4 \text { = Relatively skilled, } 5 \text { = very skilled }\end{array}$ \\
\hline & & $\begin{array}{l}\text { Compared with the self-feeling of } \\
\text { urban residents }\end{array}$ & $\begin{array}{c}1=\text { Much worse than them, } 2=\text { Worse than them, } 3=\text { Equally, } \\
4=\text { Better than them, } 5=\text { Much better than them }\end{array}$ \\
\hline & & Acceptance of new urban life & $\begin{array}{c}1=\text { Very weak, } 2 \text { = Relatively weak, } 3=\text { Commonly, } \\
4 \text { = Relatively skilled, } 5 \text { = Very skilled }\end{array}$ \\
\hline & \multirow{3}{*}{ Housing Ability } & Satisfaction with urban housing & $\begin{array}{c}1=\text { Very dissatisfied, } 2=\text { Quite dissatisfied, } 3=\text { Commonly } \\
4=\text { Quite satisfied, } 5=\text { Very satisfied }\end{array}$ \\
\hline & & $\begin{array}{l}\text { Satisfaction with public supporting } \\
\text { facilities of urban housing }\end{array}$ & $\begin{array}{c}1 \text { = Very dissatisfied, } 2=\text { Quite dissatisfied, } 3=\text { Commonly } \\
4=\text { Quite satisfied, } 5 \text { = Very satisfied }\end{array}$ \\
\hline & & $\begin{array}{l}\text { Satisfaction with urban housing } \\
\text { community facilities }\end{array}$ & $\begin{array}{c}1 \text { = Very dissatisfied, } 2=\text { Quite dissatisfied, } 3=\text { Commonly } \\
4=\text { Quite satisfied, } 5=\text { Very satisfied }\end{array}$ \\
\hline \multirow{5}{*}{$\begin{array}{l}\text { Homestead } \\
\text { Utility }\end{array}$} & \multirow{3}{*}{$\begin{array}{l}\text { Guarantee } \\
\text { Utility }\end{array}$} & Rural house living environment & $\begin{array}{c}1 \text { = Very dissatisfied, } 2=\text { Quite dissatisfied, } 3=\text { Commonly, } \\
4 \text { = Quite satisfied, } 5 \text { = Very satisfied }\end{array}$ \\
\hline & & Rural house living conditions & $\begin{array}{c}1 \text { = Very dissatisfied, } 2=\text { Quite dissatisfied, } 3=\text { Commonly } \\
4=\text { Quite satisfied, } 5=\text { Very satisfied }\end{array}$ \\
\hline & & $\begin{array}{l}\text { The homestead with a sense of } \\
\text { family belonging }\end{array}$ & $\begin{array}{c}1=\text { Totally disagree, } 2=\text { Comparative disagree, } 3=\text { commonly, } \\
4=\text { More agree }, 5=\text { Fully agree }\end{array}$ \\
\hline & \multirow{2}{*}{ Property Utility } & $\begin{array}{l}\text { Large compensation value for } \\
\text { demolition and requisition }\end{array}$ & $\begin{array}{c}1=\text { Totally disagree, } 2=\text { Comparative disagree, } 3=\text { Commonly, } \\
4=\text { More agree, } 5=\text { Fully agree }\end{array}$ \\
\hline & & Large income from homestead transfer & $\begin{array}{c}1=\text { Totally disagree, } 2=\text { Comparative disagree, } 3=\text { Commonly, } \\
4=\text { More agree, } 5=\text { Fully agree }\end{array}$ \\
\hline
\end{tabular}




\section{Appendix B. Core Independent Variables and Their Assignment in Questionnaire}

\begin{tabular}{|c|c|c|c|}
\hline & & ble Name & Variable Assignment \\
\hline \multirow{8}{*}{$\begin{array}{l}\text { Citizenship } \\
\text { Ability }\end{array}$} & \multirow[b]{2}{*}{ Economic Ability } & Annual household income (CNY 10,000) & $1=2$ or less, $2=2-6,3=7-11,4=12-16,5=16$ and above \\
\hline & & Acceptance of urban prices & $\begin{array}{c}1=\text { Totally unacceptable, } 2=\text { Less acceptable, } 3=\text { Commonly, } \\
4=\text { Quite acceptable, } 5=\text { Totally acceptable }\end{array}$ \\
\hline & \multirow{3}{*}{ Integrate Ability } & Non-agricultural livelihood skills & $\begin{array}{c}1 \text { = Very weak, } 2 \text { = Relatively weak, } 3=\text { Commonly, } \\
4=\text { Relatively skilled, } 5 \text { = very skilled }\end{array}$ \\
\hline & & $\begin{array}{l}\text { Compared with the self-feeling of } \\
\text { urban residents }\end{array}$ & $\begin{array}{c}1=\text { Much worse than them, } 2=\text { Worse than them, } 3=\text { Equally, } \\
4=\text { Better than them, } 5=\text { Much better than them }\end{array}$ \\
\hline & & Acceptance of new urban life & $\begin{array}{c}1 \text { = Very weak, } 2=\text { Relatively weak, } 3=\text { Commonly, } \\
4 \text { = Relatively skilled, } 5=\text { Very skilled }\end{array}$ \\
\hline & \multirow{3}{*}{ Housing Ability } & Satisfaction with urban housing & $\begin{array}{c}1 \text { = Very dissatisfied, } 2=\text { Quite dissatisfied, } 3=\text { Commonly } \\
4=\text { Quite satisfied, } 5=\text { Very satisfied }\end{array}$ \\
\hline & & $\begin{array}{l}\text { Satisfaction with public supporting } \\
\text { facilities of urban housing }\end{array}$ & $\begin{array}{c}1 \text { = Very dissatisfied, } 2=\text { Quite dissatisfied, } 3=\text { Commonly, } \\
4=\text { Quite satisfied, } 5=\text { Very satisfied }\end{array}$ \\
\hline & & $\begin{array}{l}\text { Satisfaction with urban housing } \\
\text { community facilities }\end{array}$ & $\begin{array}{c}1 \text { = Very dissatisfied, } 2=\text { Quite dissatisfied, } 3=\text { Commonly } \\
4=\text { Quite satisfied, } 5=\text { Very satisfied }\end{array}$ \\
\hline \multirow{5}{*}{$\begin{array}{l}\text { Homestead } \\
\text { Utility }\end{array}$} & \multirow{3}{*}{$\begin{array}{l}\text { Guarantee } \\
\text { Utility }\end{array}$} & Rural house living environment & $\begin{array}{c}1 \text { = Very dissatisfied, } 2=\text { Quite dissatisfied, } 3=\text { Commonly, } \\
4=\text { Quite satisfied, } 5=\text { Very satisfied }\end{array}$ \\
\hline & & Rural house living conditions & $\begin{array}{c}1=\text { Very dissatisfied, } 2=\text { Quite dissatisfied, } 3=\text { Commonly, } \\
4=\text { Quite satisfied, } 5=\text { Very satisfied }\end{array}$ \\
\hline & & $\begin{array}{l}\text { The homestead with a sense of } \\
\text { family belonging }\end{array}$ & $\begin{array}{c}1=\text { Totally disagree, } 2=\text { Comparative disagree, } 3=\text { commonly, } \\
4=\text { More agree, } 5=\text { Fully agree }\end{array}$ \\
\hline & \multirow{2}{*}{ Property Utility } & $\begin{array}{l}\text { Large compensation value for } \\
\text { demolition and requisition }\end{array}$ & $\begin{array}{c}1=\text { Totally disagree, } 2=\text { Comparative disagree, } 3=\text { Commonly }, \\
4=\text { More agree, } 5=\text { Fully agree }\end{array}$ \\
\hline & & Large income from homestead transfer & $\begin{array}{c}1=\text { Totally disagree, } 2=\text { Comparative disagree, } 3=\text { Commonly, } \\
4=\text { More agree } 5=\text { Fully agree }\end{array}$ \\
\hline
\end{tabular}

\section{References}

1. Yao, S.; Wu, C. A special form of urbanization of rural population in China-On China's industrial and agricultural population. J. Geogr. 1982, 37, 155-163.

2. Yang, Y. Shortage of migrant workers, semi urbanization model and urbanization model. Economist 2010, 9, 71-76.

3. $\mathrm{Fu}, \mathrm{G}$. From amphibian to triphibian: Change of migrant workers' life way and its influence. J. Northwest AF Univ. 2018, 18, 31-36, 44. [CrossRef]

4. Wang, Y.; Yan, Z.; Zhu, W.; Wang, H. Study on influencing factors and mode of action of amphibious farmers in parting with their lands in Henan. J. Shandong Acad. Agric. Eng. 2016, 33, 1-7. [CrossRef]

5. Zhang, Y.; Zhou, L.; Jia, W. Research progress and prospects on revitalization andutilization of rural residential land. J. China Agric. Univ. 2020, 25, 129-141. [CrossRef]

6. Zhang, Y.; Westlund, H.; Klaesson, J. Report from a Chinese Village 2019: Rural Homestead Transfer and Rural Vitalization. Sustainability 2020, 12, 8635. [CrossRef]

7. Long, H. Land Use Transition and Rural Transformation Development. Prog. Geogr. 2012, 31, 131-138. [CrossRef]

8. Zhang, Y. Policy Combing and Practice Comparison of Rural Homestead Withdraw with Compensation Since 2015. J. Northwest AF Univ. 2019, 19, 83-89. [CrossRef]

9. Zhao, G.; Yang, G. Analysis on Farmer's Attention of the Rural Homestead Conversion and its Influence Factors-Based on the Farm Household in Two Counties of Hubei Province. Resour. Environ. Yangtze Basin 2009, 18, 1121-1124.

10. Xu, H.; Liu, C. Research on Farmers Use House stead Circulation Wishes and Affecting Factors Based on Wuhan Jiangxis District 210 Households Questionnaire Analysts. J. Northwest AF Univ. 2012, 12, 44-49. [CrossRef]

11. Qian, L.; Qian, W.; Chen, F. Farmers' Differentiation, Expectations of Property and Rural Housing Land Transference: Based on the Survey and Empirical Analysis of Wenzhou. China Land Sci. 2015, 29, 19-26. [CrossRef]

12. Peng, C.; Wang, Q.; Zhong, Y. Rural Land Right Confirmation, Farmers' Differentiation and Willingness of Homestead Disposal: An Empirical Analysis Based on Survey Data of Anhui and Hunan Provinces. J. Nanjing Agric. Univ. 2019, 19, 118-129, 158. [CrossRef]

13. Xie, Y.; Jiang, Q. Land arrangements for rural-urban migrant workers in China: Findings from Jiangsu Province. Land Use Policy 2016, 50, 262-267. [CrossRef]

14. Lv, J.; Zhang, S. The formation factors of amphibious land occupation in rural and urban areas, the obstacles of land withdrawal system and policy suggestions-Sample analysis based on hundred village survey. Reform Econ. Syst. 2020, 2, 66-73. 
15. Zhao, B. Institutional obstacles and solutions to the "amphibious land occupation" of farmers in urban and rural areas. Agric. Econ. 2020, 3, 68-70.

16. Guan, J.; Huang, C. Microscopic Welfare and Risk Perspective of Rural Residential Land Circulation: Wuhan Survey. Reform 2013, 8, 78-85.

17. Fishbein, M.; Ajzen, I. Belief, Attitude, Intention and Behavior: An Introduction to Theory and Research. Philos. Rhetor. 1977, 10, 130-132. [CrossRef]

18. Breckler, S.J.; Wiggins, E.C. Affect versus Evaluation in the Structure of Attitudes. J. Exp. Soc. Psychol. 1989, 25, 253-271. [CrossRef]

19. Zhou, J.; Yang, Q. Review of the Researches on Rural Housing Land Transfer at Farm Household Leve. Prog. Geogr. 2012, 31, 139-148. [CrossRef]

20. Liu, S. Land Issues in Urban-Rural China. J. Peking Univ. Philos. Soc. Sci. 2018, 55, 79-93.

21. Research Group of Development Research Centre of the State Couneil. The General Situation and Strategy Orientation of the Citizenization Process of the Migrant Workers. Reform 2011, 5, 5-29.

22. Liu, T.; Zhang, Y.; Kong, X. The Citizenship ability, Land Rights Cognition and Farmers' Willingness to Quitting Land. China Land Sci. 2013, 27, 23-30. [CrossRef]

23. Yang, J. Empirical analysis of factors influencing farmers' willingness to transfer homestead-Take Xitang town of Jieyang city in Guangdong province as an example. J. Zhongkai Univ. Agric. Eng. 2016, 29, 54-58. [CrossRef]

24. Chen, M.; Kuang, F.; Lu, Y. Livelihood Capital Differentiation and Farmers' Willingness to Homestead Circulation: Based on Empirical Analysis of Jiangxi Province. J. Agro For. Econ. Manag. 2018, 17, 82-90. [CrossRef]

25. Fan, J.; Mo, J. Urbanization Style and the Pattern of Economic Development: Also on the Direction of Urbanization. Fudan J. Soc. Sci. 2013, 55, 65-73, 167.

26. Xu, Z.; Zhuo, Y.; Wu, C.; Li, G. Review on Rural Homestead Studies. Issues Agric. Econ. 2019, 4, 28-39. [CrossRef]

27. Chen, B. Rationality of Limitations on Free Transaction of Rural Residential Land. China Land Sci. 2007, 4, 44-48. [CrossRef]

28. Liu, S.; Xiong, X. Changes in Economic Structure, Village Transformation and Changes in Homestead System: A Case Study of Homestead System Reform in Luxian County, Sichuan Province. Chin. Rural Econ. 2018, 6, 2-20.

29. Zhang, K.; Fu, Z. Based on the Functional Change of the Exploration of the Land System Reform. Soc. Sci. Res. 2017, 6, 47-53.

30. Li, R.; Ye, X. Exit and Flow: Farmers' Land Disposal Choice and Influencing Factors. Rural Econ. 2019, 4, 10-20.

31. Wang, J. Rural Homestead Function and Price of Empirical Research in China, Based on the Analysis of the Function of Different Types of Peasant Household Land Preference. Price Theory Pract. 2016, 7, 93-96. [CrossRef]

32. He, X.; Huang, X. Farmland circulation can never "irreversible". Land Resour. Her. 2011, 8, 52-55.

33. Dong, $X$. The Circulation of Housing Land Use Right in the Past 70 Years Since the Founding of New China: Institutional Change, Current Dilemma and Reform Direction. Chin. Rural Econ. 2019, 6, 2-27.

34. Chen, H.; Liu, Z.; Shi, X. The Role of Land Rights and Interests on Migrant Workers' Urban-rural Migration Decision: A Case Study on 1062 Migrant Workers in a Sampling Survey of Nanjing City. Issues Agric. Econ. 2012, 33, 70-77, 111-112. [CrossRef]

35. Borjas, G.J. Self-Selection and the Earnings of Immigrants. Am. Econ. Rev. 1987, 77, 531-553.

36. Liu, C.; Zhou, L. The Urban Integration of Social Capital and Migrant Workers. Popul. Res. 2004, 5, 12-18.

37. Liu, Y.; Yang, Q. Research Advance on Farmers' Land Property Income under the Background of New Urbanization in China. Econ. Geogr. 2019, 39, 164-171. [CrossRef]

38. Chen, J.; Yang, X. The Study of the Index System for Ability Evaluation on Fusing into Cities and Towns by Migrant Workers. Urban Probl. 2012, 8, 58-63. [CrossRef]

39. Zhang, X. The Research of improving the new generation of urban migrant workers into the ability. Guizhou Soc. Sci. 2011, 7, 79-82. [CrossRef]

40. Shi, Z.; Zhu, M. Employment Stability and Social Integration of Migrant Workers. J. Zhong Nan Univ. Econ. Law 2014, 3, 49-58, 159. [CrossRef]

41. Algan, Y.; Dustmann, C.; Glitz, A.; Manning, A. The Economic Situation of First and Second-Generation Immigrants in France, Germany and the United Kingdom. Econ. J. 2010, 120, 4-30. [CrossRef]

42. Hamermesh, D.S.; Trejo, S.J. How do immigrants spend their time? The process of assimilation. J. Popul. Econ. 2013, 26, 507-530. [CrossRef]

43. Zheng, S.; Liao, J.; Ren, R.; Cao, Y. Housing Policy for Migrant Workers and Economic Growth. Econ. Res. J. 2011, $46,73-86$.

44. World Bank. World Development Report 1995; China Financial \&Economic Publishing House: Beijing, China, 1995.

45. Zhu, Z.; Leng, C. Housing Conditions, Social Status and Urban Identity of Migrant Workers: An Empirical Analysis Based on Social Integration Survey Data. China Rural. Surv. 2018, 1, 96-110.

46. Li, Y.; Liu, N.; Li, X. Farmland Circulation, Housing Choice and Peasant-Workers' Citizenization. Econ. Geogr. 2019, 39, 165-174. [CrossRef]

47. Yang, Q.; Chen, C. Economic Agglomeration, Housing Affordability and Migration Willingness of the Floating Population. Mod. Financ. Econ. J. Tianjin Univ. Financ. Econ. 2019, 39, 29-45. [CrossRef]

48. The Research of the Rural Land System Based on the Rural Hollowing out the Background Team. The Function Reconfiguration of House-site in the Countryside in the Process of Urbanization. Rural Econ. 2016, 4, 15-19.

49. Chen, X.; Jiang, X. The System of the Right to Use the Land for the House Foundation: An Analysis of its Norm, the Challenge in Practice and the Legislative Response. Manag. World 2010, 12, 1-12. [CrossRef] 
50. Chen, L.; Wang, Q.; Long, K. The Theoretical Analysis of the Influential Factors of Welfare Level by Farmers' land. Rural Econ. 2011, 12, 13-16.

51. Wang, J.; Xue, Y. How to grasp the meaning in social science--Research on interpretation method based on triangulation. Theorists 2012, 9, 85-87. [CrossRef]

52. Main Data Bulletin of the Third National Agricultural Census of Guangdong Province. Available online: http://stats.gd.gov.cn/ tjgb/content/post_1430129.html (accessed on 5 February 2021).

53. Guangdong Provincial Bureau of Statistics. Guangdong Statistical Yearbook 2021; China Statistics Press: Beijing, China, 2021.

54. Zhang, Y.; $\mathrm{Xu}, \mathrm{C}$. The compensation value composition of exiting rural residential land in the multifunctional perspective. J. Shanxi Agric. Univ. 2018, 17, 22-27. [CrossRef]

55. Peng, C. Analysis of the Influence of Peasants' Social Stratum on their Choice of Monetary Compensation Model for Leaving Their Rural Homestead: Based on Survey Data of Farmers in Anhui Province. Comp. Econ. Soc. Syst. 2013, 6, $133-146$.

56. Xu, H.; Guo, Y.; Shi, S. Analysis on the impact of farmers' differentiation on Farmers' willingness to transfer Farmland-Estimation Based on structural equation model. China Land Sci. 2012, 26, 74-79. [CrossRef]

57. Liu, T.; Niu, L. Farmers' differentiation, land withdrawal intention and farmers' choice preference. China Popul. Resour. Environ. 2014, 24, 114-120.

58. Zou, W.; Wang, Z.; Zhang, B. Study on the impact of farmers' differentiation on Rural Homestead withdrawal behavior-Based on a survey of 1456 farmers in Jiangsu Province. China Land Sci. 2017, 31, 31-37.

59. Qian, L.; Qian, W.; Zheng, S. Citizenization ability, legal cognition and rural homestead transfer-Based on the investigation and demonstration of Wenzhou Experimental Area. Agric. Econ. Issues 2016, 5, 59-68. 